\title{
Alina Kuzborska
}

\section{Rola reformacji w kształtowaniu się literatury litewskiej: fenomen Donelaitisa}

\author{
The role of the Reformation in the creation of Lithuanian literature: \\ the phenomenon of Donelaitis
}

\section{Die Rolle der Reformation in der Entwicklung der litauischen Literatur: das Phänomen von Donelaitis}

Słowa kluczowe:

Keywords:

Schlüsselwörter: reformacja, Kristijonas Donelaitis, Metai, piśmiennictwo religijne, niemiecka recepcja, litewska recepcja, tłumaczenie na polski

reformation, Kristijonas Donelaitis, Metai, religious literature, German reception, Lithuanian reception, Polish translation

die Reformation, Kristijonas Donelaitis, Metai, Religiöse Literatur, Deutsche Rezeption, Litauischer Rezeption, Polnische Übersetzung

\section{STRESZCZENIE}

Reformacja jawi się jako czynnik kulturotwórczy w powstaniu literatury litewskiej. W Litwie Pruskiej rozwijało się piśmiennictwo litewskie, począwszy od druku pierwszej książki litewskiej, katechizmu luterańskiego Martynasa Mažvydasa, który ukazał się w 1547 r. w Królewcu, ówczesnym ośrodku protestantyzmu w Prusach. W ciągu niemalże 300 lat wykształciło się tu wiele pokoleń pastorów luterańskich, przeważnie pochodzenia niemieckiego, którzy wydawali literaturę religijną na potrzeby parafii litewskich. Na podłożu oświeceniowych idei promieniujących z Królewca, a także wzmożonego ruchu wydawniczego mógł powstać pierwszy utwór o tematyce świeckiej - Metai [Pory roku] pastora luterańskiego Kristijonasa Donelaitisa. Poemat dydaktyczny o czterech porach roku, o pracy i życiu codziennym chłopów litewskich w Prusach powstał w drugiej połowie XVIII w., jednakże opublikowany został prawie 40 lat po śmierci poety. Dwujęzyczne litewsko-niemieckie wydanie Ludwika Rhesy z 1818 r. zapo- 
czątkowało podwójną recepcję dzieła Donelaitisa. W XIX w. był on znany przede wszystkim w Prusach Wschodnich, począwszy od XX w. recepcja jego dzieła przechyla się w stronę litewskości. Od okresu powojennego aż do dnia dzisiejszego nie ustają na Litwie badania nad jego twórczością, gdzie jest uważany za „ojca literatury litewskiej“. Dzieło Donelaitisa doczekało tłumaczeń na wiele języków. Polskie tłumaczenie Metai Zygmunta Ławrynowicza ukazało się w Olsztynie w 1982 roku.

\begin{abstract}
The Reformation features as a cultural force in the emergence of Lithuanian literature. Lithuanian writing developed in Prussian Lithuania, starting with the printing of the first Lithuanian book, Martynas Mažvydas's Lutheran catechism, which appeared in 1547 in Königsberg, then the centre of Protestantism in Prussia. Over the course of almost 300 years, many generations of Lutheran pastors, mostly of German origin, trained here and published religious literature for Lithuanian parishes. Reflecting the Enlightenment ideas radiating from Königsberg, as well as the increase in publishing, the first work on secular themes was Metai (the seasons) by Lutheran pastor Kristijonas Donelaitis. A didactic poem concerning the four seasons of the year, regarding the work and everyday lives of Lithuanian peasants in Prussia, it was written in the second half of the $18^{\text {th }}$ century but only published almost 40 years after the poet's death. Ludwik Rhesa's bilingual Lithuanian-German edition from 1818 facilitated a dual reception of Donelaitis's work. In the nineteenth century, he was known primarily in East Prussia, whilst in the twentieth century his work was more popular in Lithuania. From the post-war period up to the present day, research into his work continues in Lithuania, where he is considered the "Father of Lithuanian Literature". Donelaitis's work has been translated into many languages. The Polish translation of Zygmunt Ławrynowicz's Metai was published in Olsztyn in 1982.
\end{abstract}

Translated by Aleksander Pluskowski

\title{
ZUSAMMENFASSUNG
}

Die Reformation war ein wichtiger kultureller Faktor für die Herausbildung der litauischen Literatur. In Preußisch-Litauen entwickelte sich litauisches Schrifttum, mit dem Druck des ersten litauischen Buches, des lutherischen Katechismus von Martynas Mažzydas beginnend, der 1547 in Königsberg, dem Zentrum des Protestantismus, erschien. Innerhalb von beinahe 300 Jahren wurden hier mehrere Generationen der lutherischen Pfarrer ausgebildet, die vorwiegend deutscher Abstammung waren und die religiöse Literatur für Bedürfnisse der litauischen Gemeinden herausgaben. Aufgrund der aufklärerischen Ideen, die aus Königsberg ausstrahlten sowie infolge des intensiven Publikationswesens konnte das erste weltliche Werk - Metai [Die Jahreszeiten] des lutherischen Pfarrers Kristijonas Donelaitis erscheinen. Diese didaktische Dichtung über vier Jahreszeiten, über die Arbeit und den Alltag der litauischen Bauern in Preußen entstand in der zweiten Hälfte des 18. Jh., sie wurde dennoch erst beinahe 40 Jahre nach dem Tode des Dichters veröffentlicht. Die zweisprachige deutsch-litauische Ausgabe von Ludwig Rhesa aus dem Jahr 1818 begann die doppelte Rezeption des Werkes von Donelaitis. Im 19. Jh. war er in erster Linie in Ostpreußen bekannt, dann ab dem 20. Jh. beginnt seine litauische Rezeption. Seit dem Nachkrieg bis heute wird in Litauen andauernd die Donelaitis-Forschung durchgeführt, wo er für den „Vater der litauischen Literatur" gehalten wird. Das Werk von Donelaitis wurde in viele Sprachen übersetzt. Die polnische Übersetzung von Metai von Zygmunt Ławrynowicz erschien 1982 in Olsztyn. 


\section{REFORMACJA JAKO CZYNNIK KULTUROTWÓRCZY}

Reformacja $\mathrm{w}$ Prusach stała się motorem narodowotwórczym, która przyczyniła się do powstania pism w językach mniejszości narodowych, m.in. skolonizowanych w XIII w. plemion bałtyckich. Przełom luterański na początku XVI w. miał konsekwencje nie tylko religijne, lecz również świadomościowe, głównie dzięki powstaniu pisma w językach pruskim i litewskim. Znamiennym zwrotem w kulturze bałtyckich mniejszości narodowych państwa pruskiego było wydanie pierwszych książek religijnych - katechizmów Lutra w języku pruskim (1545) i litewskim (1547). Właściwie Prusowie, którzy historycznie stanowili trzon ludności autochtonicznej zsekularyzowanych Prus Książęcych i jako pierwsi otrzymali tłumaczenie katechizmu, nie byli w stanie wykorzystać dziejowej szansy i rozwinąć swojego języka, a nawet go zachować. Tak naprawdę trzy wydania katechizmu pozostają jedyną księgą i najważniejszym źródłem pisanym wymarłego dzisiaj języka, nie licząc słowników i glosariuszy dołączanych do innych książek ${ }^{1}$. Ten fakt można wytłumaczyć jedynie tym, że w dobie Reformacji Prusowie żyli w rozproszeniu, od czasu podboju minęło 300 lat, które oznaczały postępującą asymilację. Reformacja wraz z dobrodziejstwem wskrzeszania i popierania języków miejscowych przyszła do Prusów zbyt późno. Inaczej rzecz się miała z mniejszością litewską, czy raczej prusko-litewską, która żyła w skupisku głównie w historycznej Skalwii i Nadrowii, a poprzez bliskość Żmudzi, a w szerszym kontekście - Wielkiego Księstwa Litewskiego, miała w rodakach mocne zaplecze językowe i intelektualne. $\mathrm{W}$ taki sposób pierwsza książka litewska, Katechizm luterański Mažvydasa, zrodziła ruch językowy, który się ciągle rozwijał, a liczne pisma w języku litewskim w Prusach doprowadziły w XVIII w. do powstania literatury pięknej - Pór roku Kristijonasa Donelaitisa. Czesław Miłosz pisał w Szukaniu Ojczyzny o ogromnych zasługach piśmiennictwa litewskiego, które na przełomie ubiegłego wieku spełniło pewnego rodzaju misję polityczną: [...] naród ten, przegrawszy w historii, narodził się raz jeszcze $z$ filologii. ${ }^{2}$ Znamienne jest to, że kolebka filologii litewskiej znajdowała się w Prusach, a matką chrzestną nowonarodzonej była właśnie Reformacja.

Kristijonas Donelaitis (pol. Krystyn Donelajtis, niem. Christian Donalitius, 1714-1780), poeta i pastor urodzony w Prusach Wschodnich, jest postacią niezwykłą i wyjątkową w kulturze i literaturze litewskiej. Obecnie utrwalony na Litwie wizerunek „ojca literatury litewskiej”, pierwszego pisarza narodowego, jest w obrębie rodzimej literatury figurą w pewnym sensie osamotnioną. Wyrosły w tradycji

Do nielicznych źródeł języka pruskiego należą m.in. zawierający 802 słowa Słownik Elbląski z XIV w., (por.: Das Elbinger Deutsch-Preußische Vokabular: 17 Tafeln in Lichtdruck, red. A. Bezzenberger, Königsberg 1887) oraz trzy wydania Katechizmu Marcina Lutra w języku pruskim. Pierwsze wydanie tej książki ukazało się w 1545 r. w Królewcu. W tym samym roku wydano drukiem poprawioną wersję tegoż Katechizmu. Trzecie - uzupełnione i opracowane przez A. Willa wydanie ukazało się w 1561 r. w Królewcu pod nazwą Enchiridion.

C. Miłosz, Szukanie Ojczyzny, Kraków 1996, s. 38. 
nabożnego luteranizmu, wykształcony na niemieckim uniwersytecie w Królew$\mathrm{cu}$, sprawujący obowiązki duszpasterza w mieszanej parafii litewsko-niemieckiej w Tolmingkiejmach (lit. Tolminkiemis, niem. Tolmingkehmen), Donelaitis przemówił językiem prostego ludu, i to językiem poety, dźwięcznym heksametrem, przedstawiając raczej nie sielankową, tylko realistyczną idyllę chłopstwa litewskiego w Małej Litwie w przeciągu całego roku.

Donelaitis nie wyrósł jednak na kamieniu. Jego rodzimy wschodniopruski, a dokładniej prusko-litewski kontekst literacki stworzyła wielowiekowa tradycja piśmiennicza w języku litewskim: przede wszystkim pisma religijne, takie jak Biblia, kancjonały i śpiewniki, katechizmy i różnego rodzaju modlitewniki. Działaniem niejako wspierającym ruch wydawniczy, kierujący się zasadą Lutra, iż Słowo powinno przyjść do każdego w jego ojczystym języku, były liczne publikacje lingwistyczne i leksykograficzne. Autorami tego wielkiego przedsięwzięcia przed Donelaitisem (poczynając od połowy XVI aż do końca XVIII w.), a nawet po Donelaitisie (w przeciągu całego XIX w.) byli duchowni pochodzenia niemieckiego i litewskiego, którzy po studiach teologicznych na królewieckiej Albertynie i zaliczeniu lektoratów w Seminarium Litewskim (Litauisches Seminar) trafiali do litewskich parafii w Królestwie Pruskim.

Aby zrozumieć fenomen pojawienia się Donelaitisa na scenie literackiej, jego spóźnioną, dwuetapową recepcję jako poety wschodniopruskiego w XIX w. i jako pierwszego poety narodu litewskiego $\mathrm{w} \mathrm{XX} \mathrm{w}$. należy pokrótce przybliżyć historię powstania piśmiennictwa litewskiego w Prusach Wschodnich. Dwa czynniki przyczyniły się do powstania druków w języku mniejszości narodowej w obrębie państwa pokrzyżackiego: przewaga liczebna mniejszości litewskiej oraz pruskiej nad większością niemiecką na terenach północno-wschodnich oraz kwestia wyznaniowa. Chrystianizacja autochtonicznych plemion dawnych Bałtów nie przebiegała, jak wiadomo, drogą pokojową. Zakon Krzyżacki podbijał ziemie, budował kościoły, ale długo trwały kłopoty z prawdziwym nawróceniem niedawnych pogan, których należało nie tylko ochrzcić, ale też przekonać do siebie. Trudno jednakże szerzyć nową wiarę w obcym języku. Kościół katolicki w państwie zakonnym budował porozumienie $\mathrm{z}$ nowo nawróconymi poprzez tłumaczy na język pruski i litewski zwanymi „tolkami” do czasu wprowadzenia reformacji; należało bowiem tłumaczyć nie tylko kazania, ale również spowiedź. Poza tym wciąż żywe były tradycje starych wierzeń, aż do XVI w. były kultywowane pogańskie rytuały ${ }^{3}$. Po sekularyzacji Zakonu w 1525 r. jego ostatni Wielki Mistrz i pierwszy władca świecki

3 Por. M. Löwener, Der Christburger Vertrag, w: Kirche im Dorf. Ihre Bedeutung für die kulturelle Entwicklung der ländlichen Gesellschaft im „Preußenland“, 13.-18. Jahrhundert. Katalog der Ausstellung des Geheimen Staatsarchivs Preußischer Kulturbesitz in Zusammenarbeit mit der Kunstbibliothek der Staatlichen Museen zu Berlin Preußischer Kulturbesitz, Berlin 2002, s. 69-71. 
książę Albrecht Hohenzollern wprowadza luteranizm na zasadzie religii państwowej. Zmodyfikowana formuła nowego kościoła otwiera nowe możliwości wiernym, przede wszystkim dostęp do Słowa Bożego w zrozumiałym dla nich języku. Mimo to długo utrzymywał się na tych terenach synkretyzm religijny. Obok reliktów starych wierzeń zdążyły już nieco ugruntować się tradycje katolickie, tym bardziej, że granica między luterańską Litwą Pruską a katolicką Żmudzią nie była pilnie strzeżona, toteż migracja $\mathrm{w}$ obie strony była rzeczą naturalną. Żmudzini przybywali do Prus za chlebem, Litwini pruscy jeździli na odpusty za Niemen i potajemnie chrzcili swoje dzieci w obrządku katolickim ${ }^{4}$. Książę Albrecht zastosował nową politykę językową państwa i kościoła wobec ludności autochtonicznej, która stała się bodźcem do powstania piśmiennictwa litewskiego w Prusach Książęcych.

Odtąd wyznanie luterańskie i oświata wytyczały kierunek i charakter druków litewskich na ponad 200 lat. W taki sposób uczeni pochodzenia litewskiego znaleźli się wśród pierwszych profesorów założonego w 1544 r. Uniwersytetu w Królewcu: byli to Stanisław Rapagelanus (pol. Rafajłowicz, lit. Rapalionis) i Abraham Kulva (pol. Kulwieć, lit. Kulvietis). Od początków istnienia uniwersytetu można było zaobserwować zjawisko świadczące o niezwykłej przychylności nowej polityki konfesyjnej państwa pruskiego w stosunku do mniejszości narodowych: częstokroć Niemcy uczyli się litewskiego, aby dopełnić obowiązek duszpasterski w parafiach litewskich. Dbano też o to, aby wykształcić adeptów nowej wiary, wywodzących się z kręgów etnicznie litewskich. Michał Römer pisał o tych początkach:

Książę Albrecht pruski, uwzględniając brak duchownych, umiejacych po litewsku, wskutek czego kazania musiały być przez tłumaczów ludowi głoszone, rozkazał co roku po 6 młodzieńców litewskich do stanu duchownego ksztatcić i w tym celu przy zakładaniu uniwersytetu królewieckiego wyznaczyt 6 stypendyów specyalnych dla kształcenia Litwinów.

W XVI w. przepływ ludności między Wielkim Księstwem Litewskim a Prusami Książęcymi był raczej swobodny, początkowo była to migracja „ekonomiczna” z Litwy i Żmudzi na tereny Skalwii i Nadrowii, gdzie tereny po lewej stronie Niemna pozostawały po kolonizacji krzyżackiej niezaludnione lub słabo zaludnione przez autochtonicznych Litwinów i zasymilowanych Prusów ${ }^{6}$. W każdym razie byli

\footnotetext{
4 Por. J. Janavičienè, Lietuvininkų ir žemaičių ryšiai [Związki Litwinów Pruskich i Żmudzinów], w: Lietuvininku kraštas, Kaunas 1995, s. 251.

5 M. Römer, Litwini w Prusach Książęcych, „Świat Słowiański” 1911, nr. 82-84, Kraków, s. 2.

6 Kolonizacja Małej Litwy jest tematem wieloletniej polemiki uczonych litewskich i niemieckich, dotyczy ona głownie sporu o to, czy tereny byłej Skalwii i Nadrowii były skolonizowane przez napływającą z Litwy i Żmudzi ludność (wersja naukowców niemieckich, której krzewicielami byli m.in. Gertruda Heinrich i Hans Mortensenowie), czy też miejscowi Litwini odwiecznie zamieszkiwali te tereny: stanowili przewagę liczebną, a zatem też językową nad Prusami,
} 
to niepiśmienni chłopi, których świadomość religijna była w pewnym sensie rozdarta między wierzeniami plemiennymi a narzuconym katolicyzmem. Lud ten był właściwie potencjalnym odbiorcą nowej zreformowanej wiary, która miała przyjść do niego w ich własnym języku. Ta ewangelizacyjna potrzeba wymusiła nieliczny napływ elit z Wielkiego Księstwa Litewskiego, wykształconych protestantów, gotowych nauczać i krzewić naukę Lutra. Dodatkowym bodźcem do tego rodzaju migracji była szerząca się na Litwie kontrreformacja. Do grona pierwszych profesorów Albertyny należą ww. pochodzący z Litwy Stanisław Rafajłowicz oraz Abraham Kulwieć. Kluczowa rola w rozwoju piśmiennictwa litewskiego w Prusach przypadła jednak wywodzącemu się z Wielkiego Księstwa Litewskiego wydawcy pierwszej książki w języku litewskim Martynasowi Mažvydasowi, którego książę pruski Albrecht osobiście zaprosił do Królewca. Całkiem możliwe, że Mažvydas był stypendystą książęcym, jednakże przybył tu prawdopodobnie z pewnym bagażem wiedzy, albowiem w zaproszeniu książę zwraca się do niego jako „szanowanego i uczonego" męża ${ }^{7}$. Studia Mažvydas rozpoczął w 1546 r., po dwóch latach ukończył je uzyskując stopień naukowy bakałarza. Po roku nauki, czyli w 1547 r. wydaje w Królewcu dzieło, które zapoczątkowało piśmiennictwo litewskie nie tylko w Prusach, lecz również na Litwie: Catechismusa prasty szadei [Proste Słowa Katechizmu]. Jest to nie tylko katechizm, jak zapowiada tytuł, lecz również księga, zawierająca inne teksty, a mianowicie: wierszowaną przedmowę autora pt. Knigieles Paczias byla Letuuinikump jr Szemaicziump [Książeczki same przemawiaja do Litwinów i Żmudzinów], właściwie pierwszy znany tekst oryginalny w języku litewskim, następnie elementarz języka litewskiego Pygus ir trumpas mokslas skaititi ir raschiti [Łatwa i krótka nauka czytania i pisania] oraz zbiór pieśni religijnych. W późniejszym okresie te cztery teksty stały się swoistą zapowiedzią wydarzeń drukarskich w języku litewskim: katechizm zapoczątkował prace nad tłumaczeniami Biblii i innego rodzaju literatury religijnej, elementarz objawił się w różnego rodzaju pracach leksykograficznych, pieśni religijne były wielokrotnie drukowane, uzupełniane i ulepszane, a przedmowa wierszowana poniekąd przepowiedziała pierwszy utwór literacki o tematyce świeckiej: Metai [Pory Roku] Donelaitisa.

Początki reformacji nie tylko w Prusach Książęcych, ale też w Wielkim Księstwie Litewskim stały się częścią składową dorobku humanistycznego tego heterogenicznego regionu, w którym mogli zaistnieć zarówno polski protestant

co też miało doprowadzić do ich częściowej asymilacji (wśród uczonych litewskich pogląd taki głosili m.in. P. Pakarklis, S. Matulevičius, L. Gineitis i in.). Podsumowanie polemiki, która ostatecznie doprowadziła do uznania częściowej racji z obu stron, przedstawia Arthur Hermann, por.: Mažosios Lietuvos lietuviai: autochtonai ar ateiviai? Istorijografine apžvalga [Litwini Małej Litwy: atochtoni czy przybysze? Przyczynek do historiografii], w: Lietuvių ir vokiečiu kaimynystė [Sąsiedztwo litewsko-niemieckie], Vilnius 2000, s. 9-31.

7 Por. S. Žukas, Ľvadas [Wstęp] w: M. Mažvydas, Katechizmas ir kiti raštai [Katechizm i inne pisma], Vilnius 1993, s. 14. 
- humanista Mikołaj Rej, jak też jego litewski odpowiednik Martynas Mažvydas. Do końca XVI w. trwał między Litwą Wielką a Małą nie tylko przepływ ludności chłopskiej i odosobnionych uczonych mężów, lecz też wymiana myśli w postaci książek. Nie na próżno Mažvydas zwraca się w wierszowanej przedmowie do swojego katechizmu do „braci i sióstr”, mówiących tym samym językiem; przesłanie oddaje Mažvydas w obrazie narratora, samej Książki, która „przychodzi” do ludzi jako pierwszy zwiastun późniejszego Słowa w piśmie:

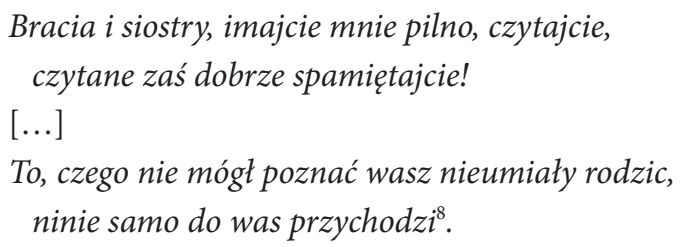

Ci „bracia” i te „siostry” to Litwini i Żmudzini, jak zapowiada przedmowa, ten sam naród po obu stronach Niemna, do których autor kierował te słowa. Pierwsza książka litewska Mažvydasa wzbudziła rezonans w Wielkim Księstwie Litewskim: otóż w dobie silnej kontrreformacji, którego centrum stała się założona w 1579 r. Akademia Jezuicka w Wilnie, wychodzą drukiem analogiczne pisma katolickie w języku litewskim, wydane przez Mikołaja Daukszę, najpierw w 1595 r. Katechizmas arba mokstas kiekwienam krikszczionii priwalus [Katechizm albo nauka każdemu chrześcijaninowi konieczna], a w 1599 r. Postilla Catholicka. Można by rzec, że ta symboliczna odpowiedź Daukszy stworzyła w Wielkim Księstwie Litewskim precedens odseparowania się od pism „kacerskich”, płynących z Prus. Odtąd rozwój piśmiennictwa religijnego w obu Litwach będzie przebiegał niesymetrycznie; podczas gdy kultura, przede wszystkim zaś piśmiennictwo litewskie w Wielkim Księstwie Litewskim zaczęły ulegać degradacji poprzez polonizację, w Prusach Książęcych wyraźnie kształtuje się tendencja sprzyjająca temu rozwojowi. Ciekawe jest to, że Dauksza, który w Przedmowie do swojego wydania ubolewa nad kondycją języka litewskiego, pisze słowa, które miały stać się jednym z najważniejszych cytatów dotyczących świadomości narodowej Litwinów, również w czasach radzieckich, przy tym pisze je po polsku:

Nie ziemi obfitościq, nie różnościq ubiorów, nie wesołością krajów, nie miast i zamków mocnością narody stoją, ale więcej zachowaniem i używaniem języka własnego, który społeczność, zgodę i miłość braterska mnoży i zachowuje [...] $]^{9}$

8 M. Mažvydas, Mówi książka Litwinom i Żmudzinom, przekł. T. Chróścielewski, w: Borussia: Ziemia i ludzie. Antologia literacka, red. K. Brakoniecki, W. Lipscher, Olsztyn 1999, s. 260-261.

9 Cyt. za: T. Venclova, Opisać Wilno (tłum. A. Kuzborska), Warszawa 2006, s. 80. 
Chociaż reformację w Wielkim Księstwie Litewskim popierały niektóre rody magnackie, np. Radziwiłlowie, protestanci na Litwie nie mieli łatwego życia. Mažvydas, podobnie jak wielu innych zwolenników protestantyzmu, musieli szukać lepszego życia w Prusach. Georg Gerullis, królewiecki bałtysta, snując rozważania o pochodzeniu Mažvydasa we wstępie do wydania dzieł zebranych autora, wyklucza jego pochodzenie z Prus lub z kraju Kłajpedzkiego, ponieważ jego litewskie teksty nie zawierają germanizmów, tylko polonizmy ${ }^{10}$. Vaclovas Biržiška ${ }^{11}$ wywodzi Mažvydasa ze Żmudzi. Saulius Žukas, wydawca jubileuszowej edycji Katechizmu Mažvydasa ze zbiorem facsimile, pisze we wstępie:

Tekst „Katechizmu” często dosłownie jest tłumaczony z polskich katechizmów Jana Seklucjana (1545), Jana Maleckiego (1546). Wykorzystano również źródła łacińskie. ${ }^{12}$

Stąd można domniemywać, że autor pierwszej książki litewskiej znał również język polski.

Piśmiennictwo litewskie w Prusach Wschodnich było z natury rzeczy piśmiennictwem religijnym, przede wszystkim były to tłumaczenia Pisma Świętego, kancjonały, katechizmy oraz tzw. książki „nabożne” (Erbauungsbücher) ${ }^{13}$. Kierunkiem „wspierającym” tego rodzaju pisma były wydania lingwistyczne: słowniki oraz gramatyki języka litewskiego. W tym sensie oświecenie w duchu konfesyjnym rozpoczęło się już z chwilą ukazania się pierwszej książki litewskiej. Od roku 1547 do 1807 w Małej Litwie ukazało się 330 książek i drobnych druków, co o 1,3 razy przewyższało wydania w Wielkim Księstwie Litewskim. Nakład książek wyznaczał poziom czytelnictwa oraz przeznaczenie druków, toteż pierwsze wydania miały mały nakład, zaledwie 200 do 300 egzemplarzy, co w zupełności zaspokajało potrzeby kościoła i szkół. Wraz ze wzrostem ludności potrafiącej czytać i pisać, zwiększył się nakład książek, przy tym wyraźnie się wykształciło się zapotrzebowanie na poszczególne druki: najmniej (zaledwie 200 do 300 egzemplarzy) przypada na różnego rodzaju agendy i pisma urzędowe, następnie (około 1000 egzemplarzy) przypada na księgi religijne - takie jak modlitewniki, kancjonały i Biblia. Największym nakładem cieszyły się zaś książki o szerszym zastosowaniu praktycznym: elementarze,

10 Por. G. Gerullis, Mosvids Leben, w: Mosvid. Die ältesten litauischen Sprachdenkmäler bis zum Jahre 1570. Hrsg. von Georg Gerullis, Heidelberg 1923, s. XIV ff.

11 V. Biržiška, Martynas Mažvydas, w: Aleksandrynas. Senujų lietuvių rašytojų, rašiusių prieš 1865 m, biografijos, bibliografijos ir biobibliografijos, t. 1, XVI-XVII amžiai, Chicago 1960, s. 77ff.

12 S. Žukas, op. cit., s. 16.

13 Por. A. Kuzborska, Rozwój litewskiego piśmiennictwa religijnego w Prusach Wschodnich do XVIII wieku, czyli rzecz o narodzie, który przetrwał dzięki filologii, Lituano-Slavica Poznaniensia. Studia Historica, X, Poznań 2004, s. 77-91. 
podręczniki i katechizmy ${ }^{14}$. Książki litewskie publikowane w Prusach Książęcych i Wschodnich są pewnego rodzaju wskaźnikiem stosunków społecznych regionu, bowiem są skierowane głównie do użytkowników, którzy nie potrafili wykształcić na przestrzeni dziejów własnej inteligencji. Główną przyczyną takiego stanu rzeczy był niski status społeczny Litwinów Pruskich, należeli oni bowiem do warstwy chłopskiej, która w tamtych warunkach społeczno-politycznych miała raczej małą szansę na awans. Dlatego byli oni prawie wyłącznie użytkownikami druków w języku litewskim, zaspokajających głównie ich potrzeby religijne. Autorami zaś byli jeszcze na początku litewskiego ruchu wydawniczego Litwini wywodzący się z Wielkiego Księstwa Litewskiego (jak już na początku wspomniałam), a od XVII w. wykształceni Niemcy, władający językiem litewskim, podobnie jak w XVIII stuleciu, kiedy duchowieństwo niemieckie pod wpływem idei Oświecenia pracowało nad nowym wydaniem Pisma Świętego, doskonaliło i wznawiało kancjonały, a wraz z wprowadzeniem szkolnictwa podstawowego - przygotowywało do druku literaturę dydaktyczno-moralną w celach wychowawczych. Literatura religijna, głównie Biblia, zbiory pieśni nabożnych i katechizm, stała się księgą uniwersalną, przez długie lata służyła ona jako podręcznik do nauki czytania i pisania, była też źródłem filologii litewskiej, doskonalonej w licznych wydaniach leksykograficznych. Przyczyniła się też do powstania literatury świeckiej, a z perspektywy XX w. - też do ugruntowania się świadomości Litwinów - jako narodu, którego najmocniejszą jednoczącą więzią był język.

\section{OD POETY WSCHODNIOPRUSKIEGO DO „OJCA LITERATURY LITEWSKIEJ"}

Wiek XVIII jest zdaniem litewskiego znawcy literatury Małej Litwy tego okresu

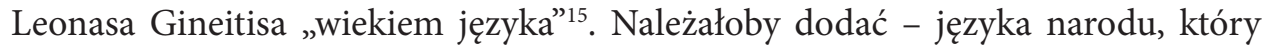
przetrwał dzięki filologii. Najwybitniejszym mistrzem tego języka był i pozostaje Kristijonas Donelaitis, albowiem stworzył on pierwsze dzieło świeckie, literacką fikcję, zbliżoną do realiów życia codziennego, dokonując tym samym sekularyzacji dotychczasowego piśmiennictwa religijnego.

Genezą świeckiej twórczości Doneliatisa było nie tylko piśmiennictwo religijne, ale również wzorce literatury antycznej (do których nawiązywał) ${ }^{16}$ i współczesnej mu literatury oświecenia europejskiego ${ }^{17}$. Dzieło życia Donelaitisa jawi się

14 Por. D. Kaunas, Mažosios Lietuvos Knyga. Lietuviškos knygos raida 1547-1940 [Książka Małej Litwy. Rozwój ksiażki litewskiej w latach 1547-1940], Vilnius 1996, s. 212-213.

15 L. Gineitis, Kristijonas Donelaitis ir jo epocha, Vilnius 1990, s. 94.

16 Por. A. Kuzborska, Donelaitis w kontekście europejskim: W kręgu literatury antycznej, Lituano-Slavica Posnaniensia. Studia Historica, X, Poznań 2004, s. 139-156.

17 Por. A. Kuzborska, Natur und Zeit in der europäischen Jahreszeitendichtung des 18. Jahrhunderts: Metai von 
jako ewenement na gruncie literatury litewskiej, jest też ciekawym przyczynkiem do badań nad literackim ruchem epoki uniwersalnego oświecenia - przez niespodziewane aktualizacje poety. Donelaitis pozostawał bowiem w konwencji literackiej idylli, zmodyfikował ją jednakże w wielkim stopniu, wprowadzając realistyczne opisy życia codziennego oraz stosunków społecznych i narodowościowych we wsi Litwy Pruskiej. Chłop (buras) Donelaitisa nie jest więc literackim uciekinierem od zgiełku miasta, tylko prawdziwym prototypem wieśniaka, jakiego on znał. $\mathrm{W}$ ten sposób autor interioryzuje język potencjalnego odbiorcy i zarazem interlokutora swojego dzieła: to pod niego i dla niego był ten utwór właściwie pisany - językiem prostym, zrozumiałym, którego ton jest raczej dydaktyczno-moralizatorski niż wzniosły, ponieważ właśnie taki był horyzont oczekiwań prostego chłopa, którego autor pragnął „oświecić” i „pouczyć”. Istnieją przesłanki, że Donelaitis czytał fragmenty swojego utworu podczas niedzielnych kazań. Jego dzieło zaistniało zatem $\mathrm{w}$ formie przekazu ustnego jeszcze przed wydaniem go w druku i pełniło zarazem funkcję estetyczną i wychowawczą.

Pierwsze dwujęzyczne wydanie Metai Kristijonasa Donelaitisa ukazało się w 1818 r. w Królewcu, 38 lat po śmierci poety. Wydawcą i pierwszym tłumaczem Donelaitisa na język niemiecki był profesor teologii Uniwersytetu Królewieckiego Marcin Ludwik Rhesa, dzięki któremu Donelaitis zaistniał najpierw w Prusach Wschodnich, a dopiero w XX w. również w Litwie. Liucija Citavičiūtė dowodzi, że poeta usiłował wydać fragmenty swojego poematu za życia ${ }^{18}$. Podobne wnioski wyciągnęłam z lektury „Przeglądu literatury Prus” Georga Christopha Pisanskiego (1725-1790), który wspomina Donelaitisa w kontekście twórców litewskich pieśni religijnych w Prusach Wschodnich. Pisanski suponuje, że Donelaitis napisał utwór „o czterech porach roku, który spotkał się z uznaniem znawców litewskiego języka i poezji ${ }^{19}$. Taka aprobata - prawdopodobnie przez autorów pieśni religijnych, którzy znali zarówno niemiecki jak też litewski - jest pierwszą wzmianką krytyczną o dziele Donelaitisa. Być może Pisanski znał niepełne tłumaczenie całego utworu: autor tłumaczenia wspomnianego fragmentu pozostaje jednak nieznany, niewykluczone, że zrobił to sam Donelaitis. Rękopis utworu przechowywała po śmierci poety jego żona, Anna Regina z domu Ohlefant. Następnie przekazała go zaprzyjaźnionemu z poetą superintendentowi z Walterkiejmów (Walterkehmen) Johannowi Gottfriedowi Jordanowi ${ }^{20}$. Z kolei Jordan przekazał oryginalny, jednakże niepełny

Kristijonas Donelaitis und The Seasons von James Thomson in der deutschen Übersetzung von Barthold Heinrich Brockes, „Studia Niemcoznawcze” 2004, nr 27, Warszawa, s. 763-781.

18 L. Citavičiūtè, Ar tiesa, kad Donelaitis rašè "tik sau“ ir neketino publikuoti savo kūrybos? [Czy to prawda, że Donelaitis pisał "tylko dla siebie” i nie zamierzał publikować swoich utworów?], w: Kristijono Donelaičio reikšmés. Straipsniu rinkinys, red. M. Vaicekauskas, Vilnius 2016, s. 81-99.

19 G.C. Pisanski, Entwurf einer preußischen Literärgeschichte in vier Büchern, Königsberg 1886, s. 663.

20 Johann Gottfried Jordan był adresatem jednego z dwóch zachowanych listów Donelaitisa. Z treści listu wy- 
manuskrypt utworu Ludwikowi Rhesie. Rhesa posiadał oprócz oryginału jeszcze odpis kompletnego utworu Donelaitisa, którego dokonał pastor Johann Friedrich Hohlfeldt z Gerwiszkiejmów (Gerwischkehmen). Nad tłumaczeniem i wydaniem Metai Rhesa pracował ponad 10 lat, ponieważ - jak pisze w Przedmowie - przeszkodą była

nieszczęsna wojna $z$ Francuzami, odpowiedzialne obowiąki kaznodziei oraz posada na uniwersytecie [...]. Chociaż Wilhelm von Humboldt, znawca kościoła i oświaty, który w 1809 roku był w Królewcu, polubił język litewski, namawiat mnie do kontynuacji mojej pracy, ale nie mogłem znaleźć na to czasu z powodu przejęcia nadzoru nad wydaniem Biblii litewskiej oraz przez przeszkody zwiąane z wyprawami wojennymi w 1913 i 1814 roku. ${ }^{21}$

W taki sposób dzieło tłumacza i wydawcy Donelaitisa ujrzało światło dzienne dopiero w 1818 r. Ta właśnie cezura czasowa zapoczątkowała badania nad życiem i twórczością „ojca literatury litewskiej”. W Przedmowie do pierwszego wydania Metai Rhesa naszkicował życiorys poety, krótką historię rękopisów poety oraz opis poszczególnych części poematu, podkreślając przy tym oryginalność autora. Dokonał przy tym wielu samodzielnych zabiegów na tekście, m.in. zatytułował poszczególne części utworu: Pavasario linksmybès [Radości wiosny], Vasaros darbai [Trudy lata], Rudenio gèrybès [Trudy jesieni], Žiemos rūpesčiai [Troski zimowe] ${ }^{22}$, jako pierwszą część opublikował Radości wiosny, mimo, iż Donelaitis prawdopodobnie najpierw napisał Trudy jesieni. Na tym nie kończy się jednak inwencja wydawcy. Rhesa, sam będąc poetą i wielkim orędownikiem i wydawcą litewskich pieśni ludowych ${ }^{23}$, „ocenzurował” Donelaitisa, wykreślając z tekstu 456 wersów: przede wszystkim nader drastyczne sceny, zbyt naturalistyczne opisy, wulgaryzmy lub zwroty niezgodne z „dobrym smakiem” zamienił na bardziej neutralne, innymi słowy upiększył styl wypowiedzi autora. Chłop Donelaitisa miał zyskać przez to na wartościach moralnych. Wydanie Rhesy nie zawiera więc scen picia, bijatyk, nie ma tu też przekleństw, których nie skąpił autor. Pierwsze wydanie Donelaitisa nie pozostało bez echa, bowiem już w tym samym roku ukazała się recenzja pióra

nika, że poeta uważał Jordana za swojego przyjaciela. Por. A. Kuzborska, Kristijonas Donelaitis' aufklärerisches Werk: Antikerezeption und deutsche Gelegenheitsdichtung, w: Das geistige Leben in Preußen in der Zeit der Frühaufklärung, red. C. Marx i B. Sapała, Olsztyn 2002, s. 98-101.

21 L.J. Rhesa, Vorbericht, w: Das Jahr in vier Gesängen, ein ländliches Epos. Aus dem Litthauischen des Christian Donaleitis, genannt Donalitius, in gleichem Versmaaß ins Deutsche übertragen von D. L[udwig] J[edemin] Rhesa Prof. d. Theol. Königsberg 1818, s. XXI.

22 Polskie tytuły poszczególnych części Metai pochodzą z wydania: K. Donelajtis, Pory roku, tłum. Z. Ławrynowicz, Olsztyn-Białystok 1982.

23 L. Rhesa, Prutena oder Preußische Volkslieder und andere vaterländische Dichtungen, Teil 1, Königsberg 1809, Teil 2, Königsberg 1825. 
Abrahama Jakoba Penzela w „Jennaische Allgemeine Literatur-Zeitung”. Recenzent wysoko ocenia walory literackie, zwłaszcza oryginalność tematyki i obrazowania poety, chwali też tłumacza za „doskonałą znajomość swojego języka ojczystego", słowa krytyki kieruje jednak pod adresem języka docelowego: wersja niemiecka Rhesy jego zdaniem "roi się od lituanizmów”24. Warto nadmienić, że recepcja pierwszego wydania sięgała daleko, została zauważona w Litwie po drugiej stronie Niemna - przez samego Adama Mickiewicza. Polski poeta w Przypisach historycznych do poematu Grażyna. Powieść litewska z 1823 r. wzmiankuje wydanie Rhesy z 1818 r.: „Das Jahr in vier Gesängen [ein ländliches Epos], aus dem Litthauischen des Christian Donaleitis, [genannt Donalitius, in gleichem Versmaaß] ins Deutsche übertragen”. W adnotacji przypisu Mickiewicz daje wierny tytuł po polsku i krótko przedstawia autora: „Rok w czterech pieśniach, z jezyka litewskiego Chr. Duonelaitisa, pastora protestanckiego z pruskiej części Litwy (w w. XVIII)”. ${ }^{25} \mathrm{O}$ samym wydawcy pisze mylnie, że był cudzoziemcem, który podobnie jak inni piśmiennicy w Litwie Pruskiej byli Niemcami, którzy nauczyli się języka litewskiego. Rhesa pochodził z Mierzei Kurońskiej, a język litewski poznał z dzieciństwa. Monumentalne wydanie Dzieł Rhesy przygotowuje Litewski Instytut Literatury i Folkloru. Są to tłumaczenia Donelaitisa, pisma teologiczne, tłumaczenie biblii, litewskie dajny, czyli pieśni ludowe. ${ }^{26}$ Mickiewicz pisał o nim m.in.:

Rhesa jest podobno teraz profesorem w Królewcu, mitośnik starożytności litewskich, ogłasza zabytki ich literatury. Przed kilku laty wydat poema Litwina Donalejtysa o czterech porach roku, heksametrem napisane, z przydaniem tlumaczenia niemieckiego i uczonych objaśnień. Wspomnione poema, co do rzeczy i pięknego wystowienia godne pochwaty, i stąd jeszcze mieć powinno dla nas szczególny interes, iż jest wiernym obrazem obyczajów ludu litewskiego. Dzięki szanownemu mężowi, który, lubo cudzoziemiec, zawstydzat rodaków, mało dbatych o historia swojej ojczyzny. ${ }^{27}$

Następne wydanie Donelaitisa przygotował do druku wybitny językoznawca August Schleicher ${ }^{28}$, profesor Uniwersytetu w Jenie. Dzieło poety z Małej Litwy interesowało go przede wszystkim z punktu widzenia lingwistycznego. Jego petersburskie wydanie zawiera tylko oryginalną, litewską wersję; w celu zrozumienia tekstu edytor umieszcza jedynie glosariusz litewsko-niemiecki. Schleicher

24 J.A. Penzel, Das Jahr in vier Gesängen, „Jenaische Allgemeine Literatur-Zeitung“ 1818, Nr. 152, Jena, s. 297-304.

25 A. Mickiewicz, Grażyna. Przypisy historyczne, w: A. Mickiewicz, Dzieła, tom II: Poematy, Warszawa 1994, s. 55.

26 M.L. Rėza, Raštai, T. 1-5, Vilnius 2011-2018.

27 A. Mickiewicz, op. cit., s. 55

28 A. Schleicher, Christian Duonaleitis Litauische Dichtungen. Eine vollständige Ausgabe mit Glossar, St. Petersburg 1865 . 
wzorował się częściowo na wydaniu Rhesy, wniósł jednak wiele cennych udoskonaleń. Jak sugeruje podtytuł jego publikacji Donelaitisa - miało to być „pełne wydanie z glosariuszem”; oprócz tych nowości Schleicher uzupełnił tekst oryginału i dodał komentarze. Opublikował również sześć bajek Donelaitisa, o których Rhesa wspomniał w Przedmowie do Metai i wydał w 1824 r. razem ze swoimi tłumaczeniami bajek ezopowych z greki na litewski ${ }^{29}$. Tym niemniej inny lingwista Heinrich Ferdinand Nesselmann, profesor Uniwersytetu Królewieckiego cztery lata później ponownie wydaje Donelaitisa w wersji dwujęzycznej. Sam dokonuje nowego - drugiego tłumaczenia Metai oraz bajek, zamieszcza też dwa zachowane listy poety, komentarze i glosariusz. Nesselmann nie daje tytułu całemu utworowi - zachowując tym samym wierność rękopisom, poszczególne utwory oznacza rzymskimi cyframi: sześć bajek - według utrwalonego w piśmiennictwie przekonania, że bajki powstały przed Metai, następnie samodzielny fragment Pór roku (Fritzens Erzählung von der littauischen Hochzeit [Opowieść Frycka o litewskim weselu - A.K.]), na końcu zaś cztery części dzieła głównego. W ten sposób wydanie zawiera XI utworów wierszowanych Donelaitisa. Tłumaczenie Nesselmanna jest raczej filologiczne, bardzo dokładne, na czym niewątpliwie ucierpiały walory poetyckie utworu. Tym niemniej krytyka dobrze przyjęła nową edycję Donelaitisa; periodyki niemieckie na przełomie lat 70. niewątpliwie przyczyniły się do upowszechnienia dzieła poety prusko-litewskiego w niemieckim kręgu kulturowym ${ }^{30}$.

W końcu XIX w. Donelaitis doczekał się kolejnego, już czwartego wydania i trzeciego tłumaczenia. Autorem poetyckiego przekładu Donelaitisa jest literat i publicysta Ludwik Passarge, który dobrze znał język litewski, ponieważ zgłębiał jego tajniki u wybitnego bałtysty Fryderyka Kurschata na uniwersytecie w Królewcu. Książka - tym razem tylko w wersji niemieckiej - ukazała się w $1894 \mathrm{rr}^{31}$. Passarge konstruuje swoje wydanie podobnie jak Nesselmann, z jedyną różnicą, że utworowi nadaje tytuł: Die Jahreszeiten, ponadto do druku użyto łacińskiej czcionki, podczas gdy poprzednie edycje były drukowane frakturą. W artykule wstępnym Donalitius' Leben und Dichtungen [Życie i twórczość Donalitiusa] wydawca przedstawia przegląd poprzednich wydań Donelaitisa, motywując potrzebę kolejnej edycji - tym razem tylko w języku niemieckim. Jest to zarazem akt symboliczny $\mathrm{w}$ niemieckiej recepcji autora, albowiem w tym momencie dokonała się „adaptacja" Donelaitisa dla kultury niemieckiej. Poprzednie wydania mniej lub bardziej dokładnie inwentaryzowały litewski dorobek poety, dodając swoje tłumaczenia. Schleicher z pobudek czysto lingwistycznych wydał sam oryginał - jako dokument

29 Aisopas arba Pasakos iß Grykonu kalbos pergulditos par par D[oktor] L. Rhesa. Su pridejimu kellu nauju Pasaku, Karaliaucßuje 1824.

30 Recenzje edycji Nesselmanna zamieściły m.in. „Altpreußische Monatsschrift“ 1870, nr 7, s. 48-49; „Beiträge zur vergleichenden Sprachforschung“ 1870, nr 6, s. 475-485.

31 C. Donalitius, Littauische Dichtungen. Übersetzt und erläutert von L. Passarge, Halle 1894. 
ważnego w badaniach indoeuropeistycznych języka, jakim jest litewski. Passarge podziwia Donelaitisa, że potrafił ten język ludu wznieść na takie wyżyny, jednocześnie uważa, że poeta nie zawsze sobie radził w wysłowieniu: tam, gdzie jego litewski nie był w stanie sprostać narracji i obrazowaniu, posłużył się niemieckim - „niczym swoim drugim językiem ojczystym”32, stąd też tak wiele germanizmów znalazło się w tekście. Passarge cały czas nawiązuje w swoim artykule do wschodniopruskiego powinowactwa Donelaitisa, zwłaszcza w części biograficznej, gdzie obok atrybutu „litewski” pojawia się korygujące określenie „nasz”.

W taki sposób całkowicie zmienił się odbiorca utworu Donelaitisa. Na początku była mowa o tym, że autor wyraźnie adresował swe dzieło do chłopa litewskiego, dla niego być może wystylizował zrozumiały język w stylu niskim, chociaż całości nadał formę klasycznego (nie rymowanego) heksametru, był on więc „potencjalnym odbiorcą". Cała XIX-wieczna historia związana z publikacjami dzieła życia Donelaitisa wskazuje na to, że to uczeni, filolodzy, wykształceni stali się „właściwymi odbiorcami" utworu. Wobec tego zrozumiała staje się tendencja - coraz bardziej zmierzająca do „zaadoptowania” (by nie rzec germanizacji) Donelaitisa. Dlatego też XIX-wieczna recepcja Donelaitisa została tu określona jako niemiecka.

Przedostatnie tłumaczenie Metai autorstwa Buddensiega z 1966 r. leży w innej konwencji. Wprawdzie jest to edycja jednojęzyczna, tylko niemiecka, temat podziału na "nasz” czy „nie nasz” tu zupełnie nie istnieje. Autor oryginału nazywa się bowiem Kristijonas Donelaitis, który w czasie pracy nad tłumaczeniem obchodziłby swój 250-letni jubileusz urodzin, i już był postrzegany przez świat kultury - nie tylko litewskiej - jako litewski klasyk urodzony w Prusach Wschodnich, dokładnie w Małej Litwie. Na takie stwierdzenie składa się historia litewskiej recepcji Donelaitisa, którą wyznacza wiek XX. W 2016 r. ukazało się nowe, piąte już tłumaczenie dzieła życia pastora protestanckiego z Malej Litwy na język niemiecki. Tłumaczem jest Gottfried Schneider ${ }^{33}$, pastor luterański, który na początku lat 90. przybył do parafii luterańskiej w Wilnie, później był wykładowcą na Wydziale Teologii na Uniwersytecie w Kłajpedzie. Gottfried Schneider zbudował Donelaitisowi most między XVIII a XXI w., pokazał, że jego dzieło można odczytać we współczesnym, zrozumiałym języku.

W XX w. Donelaitis staje się litewskim poetą, „ojcem literatury litewskiej”. Już w okresie międzywojennym wiele uwagi poświęcono życiu i twórczości poety. W Litwie Radzieckiej, zwłaszcza w roku jubileuszowym 250. rocznicy urodzin poety ukazały się dzieła zebrane, bibliografia oraz liczne opracowania ${ }^{34}$. W Litwie

32 Ibidem, s. 6.

33 K. Donelaitis, Die Jahreszeiten. Aus dem Litauischen übersetzt von G. Schneider. Mit historischen und bio-bibliographischen Hinweisen von A. Kelletat, Ebenhausen bei München 2016.

${ }^{34}$ Por. E. Lebedienė, Kristijono Donelaičio bibliografija, Vilnius 1964; K. Korsakas, Aktualieji donelaitikos užda- 
niepodległej zainteresowanie twórczością Donelaitisa nie słabnie. Od lat 90. literaturoznawstwo litewskie zajmuje się twórczością pierwszego poety litewskiego. W popularnych w Litwie badaniach semiotycznych (Saulius Žukas) czy poststrukturalistycznych (Tomas Venclova) od nowa odczytują się treści dzieła poety z Prus Wschodnich. Donelaitis jawi się więc nie tylko jako wieszcz litewski, lecz również uczestnik procesu literackiego XVIII w., który czerpał ze źródeł duchowej kultury europejskiej, a jest to spojrzenie wychodzące poza ramy litewskiej donelaityki. Przełomową okazała się monografia pióra Dali Dilyte, która dotyczy powiązań twórczości poety z literaturą antyczną, co świadczy o nowych próbach „europeizacji" i przekraczania granic stricte narodowych w sposobie odczytania dzieła Donelaitisa ${ }^{35}$.

Pamięć kulturowa na Litwie ma się dobrze, gdyż tutaj czci się bohaterów przeszłości i ojców-założycieli, których jubileusze są fetowane w programach narodowych. Wielkim jubileuszem było upamiętnienie w 1997 r. 450. rocznicy pierwszej książki litewskiej, Katechizmu Martynasa Mažvydasa. Rok 2014 obfitował w liczne wydarzenia naukowe i kulturalne, a także publikacje z okazji 300 lat urodzin Donelaitisa. Pory roku zostały po raz pierwszy przetłumaczone na język hiszpański ${ }^{36}$ i włoski ${ }^{37}$. Odnotowano również kolejne ważne edycje poświęcone Donelaitisowi: I tom Dzieł krytycznych ${ }^{38}$ oraz monografie naukowe ${ }^{39}$.

\section{POLSKI DONELAITIS}

Pierwsze tłumaczenia Metai Donelaitisa na język polski powstały już w XIX w. Przekłady Mikołaja Akielewicza (Akelaitisa) oraz Jana Aleksandra Karłowicza pozostały w rękopisach. Fragmenty utworu opublikowali Jan Ossowski, słuchacz studiów bałtystycznych na Uniwersytecie Królewieckim oraz Julia Wichert-Kajruksztisowa, poetka i tłumaczka. Pełne polskie tłumaczenie ogłosił drukiem Kazimierz Pietkiewicz w Warszawie w 1933 r. Z dwóch polskich przekładów Metai Donelaitisa na szczególną uwagę zasługuje tłumaczenie Zygmunta Ławrynowicza. Książka ukazała się w 1982 r. w olsztyńskim wydawnictwie Pojezierze ze wstępem

viniai, w: Literatūra ir kalba, VII: Kristijonas Donelaitis, red. K. Korsakas, Vilnius 1965; K. Donelaitis, Raštai. Lietuvos TSR Mokslu Akademija. Lietuvių kalbos ir literatūros Institutas, red. K. Korsakas, Vilnius 1977.

35 D. Dilyte, Kristijonas Donelaitis ir antika, Vilnius 2005.

36 K. Donelaitis, Las estaciones del año, edición y traducción de C. Caro Dugo, introducción de D. Pociūtè-Abukevičienè, ilustraciones Š. Leonavičius, red. poetica de R.A. Caballero, (ser. Colección Poesía universal. Seria menor, 7), Valencina de la Concepción: Renacimiento, 2013.

37 K. Donelaitis, Le stagioni. Il poema nazionale lituano. Traduzione e cura A. Cerri. Joker Edizioni 2014.

38 K. Donelaitis, Raštai I tomas: Metai. Dokumentinis ir kritinis leidimas, red. M. Vaicekauskas, Vilnius 2015.

39 M. Vaicekauskas, Kristijono Donelaičio reikšmess [Znaczenia Kristijonasa Donelaitisa], Vilnius 2016; D. Razauskas-Daukintas, Mitiniai vaizdiniai Donelaičio „Metuose“ [Wyobrażenia mityczne w „Metai” Kristijonasa Donelaitisa], Vilnius 2016. 
Andrzeja Wakara i samego autora przekładu ${ }^{40}$. Tłumaczenie jest literacko nienaganne, ponieważ dokonał go poeta i tłumacz. Urodzony w 1925 r. w Poniewieżu Ławrynowicz przebył trudną drogę żołnierza i emigranta. W $1943 \mathrm{r}$. został wywieziony do Niemiec do pracy przymusowej, w 1944 r. przedostał się do Włoch, gdzie wstąpił do 2 Korpusu Polskiego. Od 1946 r. mieszkał w Wielkiej Brytanii, gdzie od 1955 r. był redaktorem „Merkuriusza Polskiego”, w latach 1958-1959 współredagował miesięcznik „Życie”, był członkiem zespołu redakcyjnego „Kontynentów”. W swoich wierszach nawiązywał do motywów biblijnych, tłumaczył z różnych języków: angielskiego, włoskiego i litewskiego. Zmarł w Londynie w 1987 r.

Poemat Donelaitisa Metai tłumacz zatytułował Pory roku, a napisany heksametrem utwór przetłumaczył trzynastozgłoskowcem, który w polszczyźnie oddycha naturalnie (podobnie jak poemat Adama Mickiewicza Pan Tadeusz). Polska edycja Donelaitisa jest dwujęzyczna: czytelnik ma możliwość porównania i oszacowania tłumaczenia. To, że Ławrynowicz doskonale znał litewski, i to, że sam był poetą, jest w dużej mierze przyczyną sukcesu przekładu. Trudno byłoby dziś zmierzyć się z dziełem tak odległym czasowo, a także z tłumaczeniem tak doskonałym, aby od nowa przetłumaczyć Donelaitisa na język polski.

Dzieło życia Donelaitisa Metai (Pory roku) jest panoramą życia chłopów pańszczyźnianych w Prusach. Obserwujemy ich troski i niewielkie przebłyski radości przez cały rok: od wiosny do zimy. Cztery pieśni, odmierzające rytm życia w toku zmieniających się pór roku, rozpoczynają się od opisu przyrody, chwalą dzieło Stwórcy, gdyż przyroda jest jego doskonałym dziełem. Pastor Donelaitis cały czas do Niego się odwołuje, gdyż to dzięki Niemu wszystko się dzieje, to On dał ptakom niebo, zwierzętom polany i knieje, a ludziom kazał sumiennie pracować:

\section{Lecz bez ciebie, Ojczulku Niebieski nad nami, \\ Na nic sa dla nas piękne obietnice lata. \\ $[\ldots]$ \\ Pozwoliteś nam przetrwać ten rok, co przeminat, Przeżyjemy następny jeśli wola Twoja. ${ }^{41}$}

Panoramiczny świat Donelaitisa jest dychotomiczny, lecz jednocześnie uniwersalny, są tu rzeczy i zjawiska, które są dane, i które funkcjonują według określonego porządku w czasie i przestrzeni. Przestrzeń burasa (chłopa) prusko-litewskiego jest raczej zamknięta: koncentruje się wokół trosk życia codziennego, gdzie dom i ogród należy do kobiet, pola zaś do mężczyzn. Przestrzeń geograficzna nie odgrywa większej roli, ponieważ rzeczy mogą się wydarzać w każdym miejscu

${ }^{40}$ K. Donelajtis, Pory roku....

${ }^{41}$ Ibidem, s. 205. 
Litwy Pruskiej. Kilkakrotnie padają nazwy miejscowości: Taukai i Vyžlaukis, również miasto Królewiec (Karaliaučius). To stolica, Królewiec, którą Donelaitis dobrze znał z czasów swoich studiów na Albertynie jest najjaskrawszym kontrastem świata codziennego burasów. To duże miasto, gdzie życie toczy się inaczej, a gorliwy duszpasterz przestrzega swoich parafian, że stąd pochodzi zło wszelakie, zgubne mody, tu mieszkają panowie - wcielenie zepsucia moralnego, którzy grają w karty i objadają się wszelkim paskudztwem w rodzaju żab (tak Donelaitis zohydzał ziomkom uroki stołu pańskiego, gdzie pojawiały się ostrygi i inne wymyślne dania). Wreszcie w Królewcu zostaje śmiertelnie pobity poczciwy sołtys Pričkus (protagonista nie do końca wyraźnego wątku utworu). Donelaitis piętnuje wielkomiejskie obyczaje, tym samym napominając chłopom o ich obowiązkach i miejscu na tym padole łez: tylko uczciwą pracą, przestrzeganiem praw boskich i nakazów królewskich mogą zasłużyć na lepszy los. Poeta pokazuje na przestrzeni tekstu swoje przywiązanie do porządku, również społecznego, jest wiernym poddanym króla pruskiego, pogodzonym $\mathrm{z}$ istniejącym ładem. Na przedstawionej w poemacie płaszczyźnie społecznej obserwujemy różne grupy: chłopów i panów. Najważniejsi są jednak chłopi pańszczyźniani, którzy są bohaterem zbiorowym utworu. Czasami do słowa dochodzą mniej lub bardziej samodzielni chłopi, tacy jak sołtys Pričkus, czy też pracowici i nabożni jak Selmas i Lauras. Ci ostatni wypowiadają się negatywnie o obcych - Niemcach, Francuzach (potomkach zbiegłych hugenotów) i mieszkających obok nich Szwajcarach, prawdopodobnie Salzburczykach, którzy osiedlili się w sąsiednich parafiach opustoszałych po wielkiej dżumie $1711 \mathrm{r}$ :

Niemiaszki nas Litwinów za cymbałów mają,
Na nasz widok śmieją się francuskie przybłędy.
Śmieja się, ale chleb nasz aż pod niebo chwala
I kiełbasy wędzone pałaszują chętnie.
[...]
Ty, francuski bęcwale, $z$ Szwajcarem brzuchatym
I inni, coście Litwę uciskać się zbiegli,
Kto wam dał prawo szargać naszym ludem, nami?2

Na płaszczyźnie moralno-obyczajowej to właśnie ci obcy byli nosicielami zła wszelkiego. W sensie cywilizacyjnym stali wyżej niż Litwini, mieli lepsze warunki gospodarcze, często posiadali status wolnych, byli liczniejsi i bardziej zbliżeniu do miasta. To sprawiało, że duszpasterz widział w nich zagrożenie dla swoich litewskich ziomków: naśladując ich, Litwini tracili swoją tożsamość, język i obyczaje, ubierali się

42 Ibidem, s. 197. 
na wzór niemiecki, częściej zaglądali do karczmy niż do kościoła. Tym większy był żal do przybyszów, że zakłócali stary porządek sprzed kolonizacji, albowiem to Litwini byli od wieków gospodarzami tej ziemi. Pozytywne świadectwo poeta wystawia jedynie niemieckim kobietom (sam miał żonę Niemkę), które są bardziej gospodarne i pracowite, a produkty zdobyte ciężką pracą potrafią korzystnie sprzedać. Takie cnoty byłyby przydatne również litewskim kobietom. Dalszą opozycję do chłopów stanowią mieszczuchy, którzy nie tylko mają za nic biednych chłopów, jedzą dziwne potrawy, inaczej się ubierają, ale też przez wszystkie swoje niecne uczynki „biegną prosto do piekła”. Litwinom Donelaitis przypisuje grzechy dnia powszedniego, bardziej przyziemne, takie jak pijaństwo, lenistwo, niedbalstwo etc., podczas gdy Niemcy grzeszą nawet bardziej. Pastor zarzuca im bezbożność i upadek moralny.

W obrazach życia chłopów widzimy wiele cennych szczegółów obyczajowych, są tu opisy wesela i chrzcin, zarówno jak szczegóły dotyczące jedzenia i picia, ubiorów i pracy. Właśnie te wątki najbardziej przykuły uwagę młodego Mickiewicza. Nad wszystkim czuwał uważny duszpasterz, który strofował, pouczał, napominał i udzielał cennych wskazówek. Poezja Donelaitisa zrodziła się z obserwacji życia, które zamyka się w cyklu jednego roku, który jest powtarzalny i toczy się kołem. Taki bieg i przewidywalność rzeczy i zjawisk tworzy pewnego rodzaju makrokosmos wieśniaka, czego świadectwem jest nieokreślony wiek bohaterów, zarówno jak stopień ich spowinowacenia. Autor często używa słów i zwrotów określających częstotliwość, np. „co roku”, „codziennie”, „rano”, wieloznacznych „wczoraj” i inne. Donelaitis udokumentował zaiste niepoetyckie życie Litwinów pruskich z punktu widzenia konserwatywnego pastora protestanckiego. Kochał swoich ziomków i ich bronił, jednakże nie wybaczał im nawet drobnych przewinień, ponieważ czuł się Litwinem w sensie etnicznym. Z drugiej strony należał również do grupy „obcych”, czyli Niemców, z którymi studiował na uniwersytecie i z którymi się przyjaźnił. Dokonał rzeczy niebywałej: udowodnił, że prosty chłopski język nadaje się do poezji, i to nie byle jakiej, lecz pisanej klasycznym heksametrem. W końcu XVIII w. przemówił o antagonizmach narodowościowych, wyprzedzając czas, ponieważ o tym zaczęło się mówić i pisać dopiero pod koniec XIX w.

Donelaitisa znają dzisiaj uczniowie wszystkich szkół na Litwie, nie tylko litewskich, lecz również polskich i rosyjskich. Świadomość tego zjawiska „upowszechnienia" potwierdzają liczne miejsca pamięci Donelaitisa również w kulturze materialnej: w największych miastach Litwy można zobaczyć jego pomniki, istnieją nazwy ulic i szkół jego imienia. W Tolminkiejmach (obecnie miejscowość Czistyje Prudy w obwodzie Kaliningradzkim), gdzie spędził większość swojego życia, władze litewskie (naówczas jeszcze radzieckie) zatroszczyły się o odbudowanie kościoła i domu parafialnego, gdzie mieści się obecnie muzeum Donelaitisa. 
Donelaitis był pierwszym poetą języka litewskiego, a przed nim była bogata literatura religijna w tym języku, którą zapoczątkował Mažvydas. Donelaitis nie doczekał się następców jedynie w tym sensie, że nikt po nim nie napisał poematu dydaktycznego heksametrem. Ale za nim stoi cała późniejsza literatura litewska, łącznie ze współczesną, a to mianowicie dlatego, że poezja opisowa, taka, która sprzeciwia się naiwnemu liryzmowi, mówiąca dosadnie o rzeczach trudnych bądź codziennych, poezja prześmiewcza i krytyczna, ale też pełna ciepła dla zwykłych ludzi - pochodzi właśnie od Donelaitisa. Jest on ojcem opisu poetyckiego bezpruderyjnie drastycznej rzeczywistości, dziarskiego humoru i nietypowych bohaterów, jaki cechuje współczesną litewską lirykę. Reformacja w Prusach była bodźcem do świadomego używania języka narodowego. Litwini potrafili tę dziejową szansę wykorzystać. Ponad 300 lat po ukazaniu się Katechizmu litewskiego w Prusach powstaje pierwszy utwór wierszowany o tematyce świeckiej autorstwa pastora protestanckiego, który miał poczucie humoru, talent poetycki i wielki szacunek do każdej pracy - w duchu konfesji luterańskiej.

\section{BIBLIOGRAFIA}

\section{Źródła:}

Donalitius Christian, Littauische Dichtungen. Übersetzt und erläutert von L. Passarge, Halle 1894.

Donelaitis Kristijonas, Raštai. Lietuvos TSR Mokslų Akademija. Lietuvių kalbos ir literatūros Institutas, red. K. Korsakas, Vilnius 1977.

- Las estaciones del año, edición y traducción de C. Caro Dugo, introducción de D. Pociūtè-Abukevičienè, ilustraciones Š. Leonavičius, red. poetica de R.A. Caballero, (ser. Colección Poesía universal. Seria menor, 7), Valencina de la Concepción: Renacimiento 2013.

- $\quad$ Le stagioni. Il poema nazionale lituano. Traduzione e cura A. Cerri. Joker Edizioni 2014.

- $\quad$ Raštai I tomas: Metai. Dokumentinis ir kritinis leidimas, red. M. Vaicekauskas, Vilnius 2015.

- Die Jahreszeiten. Aus dem Litauischen übersetzt von G. Schneider. Mit historischen und bio-bibliographischen Hinweisen von A. Kelletat, Ebenhausen bei München 2016.

Donelajtis Krystyn, Pory roku, tłum. Z. Ławrynowicz, Olsztyn-Białystok 1982.

Mažvydas Martynas, Mówi książka Litwinom i Żmudzinom, przekł. T. Chróścielewski, w: Borussia: Ziemia i ludzie. Antologia literacka, red. K. Brakoniecki, W. Lipscher, Olsztyn 1999.

Mickiewicz Adam, Grażyna. Przypisy historyczne, w: A. Mickiewicz, Dzieła, tom II: Poematy, Warszawa 1994.

Miłosz Czesław, Szukanie Ojczyzny, Kraków 1996.

Rhesa Ludwig J[edimin], Vorbericht, w: Das Jahr in vier Gesängen, ein ländliches Epos. Aus dem Litthauischen des Christian Donaleitis, genannt Donalitius, in gleichem Versmaaß ins Deutsche übertragen von D. L[udwig] J[edemin] Rhesa Prof. d. Theol. Königsberg 1818.

- $\quad$ Prutena oder Preußische Volkslieder und andere vaterländische Dichtungen, Teil 1, Königsberg 1809, Teil 2, Königsberg 1825.

Rèza Martynas Liudvikas, Raštai, T. 1-5, Vilnius 2011-2018.

Schleicher August, Christian Duonaleitis Litauische Dichtungen. Eine vollständige Ausgabe mit Glossar, St. Petersburg 1865 .

Venclova Tomas, Opisać Wilno (tłum. A. Kuzborska), Warszawa 2006.

\section{Opracowania:}

Biržiška Vaclovas, Martynas Mažvydas, w: Aleksandrynas. Senujų lietuvių rašytojų, rašiusiu prieš 1865 m, biografijos, bibliografijos ir biobibliografijos, t. 1, XVI-XVII amžiai, Chicago 1960.

Citavičiūtè Liucija, Ar tiesa, kad Donelaitis rašè „tik sau“ ir neketino publikuoti savo kūrybos? [Czy to prawda, że Donelaitis pisał „tylko dla siebie“ i nie zamierzał publikować swoich utworów?], w: red. M. Vaicekauskas, Kristijono Donelaičio reikšmès. Straipsnių rinkinys, Vilnius 2016. 
Das Elbinger Deutsch-Preußische Vokabular: 17 Tafeln in Lichtdruck, red. A. Bezzenberger, Königsberg 1887.

Dilyte Dalia: Kristijonas Donelaitis ir antika, Vilnius 2005.

Gerullis Georg, Mosvids Leben, w: Mosvid. Die ältesten litauischen Sprachdenkmäler bis zum Jahre 1570, red. G. Gerullis, Heidelberg 1923.

Gineitis Leonas, Kristijonas Donelaitis ir jo epocha, Vilnius 1990.

Hermann Arthur, Mažosios Lietuvos lietuviai: autochtonai ar ateiviai? Istorijografine apžvalga [Litwini Małej Litwy: atochtoni czy przybysze? Przyczynek do historiografii], w: Lietuvių ir vokiečiu kaimynystė [Sąsiedztwo litewsko-niemieckie], Vilnius 2000.

Janavičienė Janina, Lietuvininku ir žemaičiu ryšiai [Związki Litwinów Pruskich i Żmudzinów], w: Lietuvininkų kraštas, Kaunas 1995.

Kaunas Domas, Mažosios Lietuvos Knyga. Lietuviškos knygos raida 1547-1940 [Książka Małej Litwy. Rozwój książki litewskiej w latach 1547-1940], Vilnius 1996.

Korsakas Kostas, Aktualieji donelaitikos uždaviniai [Aktualne zadania donelaityki], w: Literatūra ir kalba, VII: Kristijonas Donelaitis, red. K. Korsakas, Vilnius 1965.

Kuzborska Alina, Kristijonas Donelaitis' aufklärerisches Werk: Antikerezeption und deutsche Gelegenheitsdichtung, red. C. Marx, B. Sapała: Das geistige Leben in Preußen in der Zeit der Frühaufklärung, Olsztyn 2002.

- Donelaitis $w$ kontekście europejskim: W kręgu literatury antycznej, Lituano-Slavica Posnaniensia. Studia Historica, X, Poznań 2004.

- $\quad$ Natur und Zeit in der europäischen Jahreszeitendichtung des 18. Jahrhunderts: Metai von Kristijonas Donelaitis und The Seasons von James Thomson in der deutschen Übersetzung von Barthold Heinrich Brockes, w: red. L. Kolago, „Studia Niemcoznawcze” 2004, nr 27, Warszawa.

- $\quad$ Rozwój litewskiego piśmiennictwa religijnego w Prusach Wschodnich do XVIII wieku, czyli rzecz o narodzie, który przetrwał dzięki filologii, w: Lituano-Slavica Poznaniensia. Studia Historica, X, Poznań 2004.

Lebedienè Elena, Kristijono Donelaičio bibliografija, Vilnius 1964.

Löwener Marc, Der Christburger Vertrag, w: Kirche im Dorf. Ihre Bedeutung für die kulturelle Entwicklung der ländlichen Gesellschaft im „Preußenland“, 13.-18. Jahrhundert. Katalog der Ausstellung des Geheimen Staatsarchivs Preußischer Kulturbesitz in Zusammenarbeit mit der Kunstbibliothek der Staatlichen Museen zu Berlin Preußischer Kulturbesitz, Berlin 2002.

Penzel Jakob Abraham, „Das Jahr in vier Gesängen“, „Jenaische Allgemeine Literatur-Zeitung”, Jena 1818, Nr. 152. Pisanski Georg Christoph, Entwurf einer preußischen Literärgeschichte in vier Büchern, Königsberg 1886.

Razauskas-Daukintas Dainius, Mitiniai vaizdiniai Donelaičio „Metuose“ [Wyobrażenia mityczne w „Metai” Kristijonasa Donelaitisa], Vilnius 2016.

Römer Michał, Litwini w Prusach Książęcych, „Świat Słowiański” 1911, nr. 82-84, Kraków 1911.

Vaicekauskas Mikas, Kristijono Donelaičio reikšmès [Znaczenia Kristijonasa Donelaitisa], Vilnius 2016.

Žukas Saulius, Ivadas [Wstęp], w: Martynas Mažvydas, Katechizmas ir kiti raštai / Catechismus und andere Schriften, Vilnius 1993. 